\title{
Japanese Animals in Calamity
}

\subsection{The Impact of Disasters on Companion Animals}

In 2011, a tsunami hit the northeast coast of Japan, resulting in the loss of many lives and the explosion of a nuclear power plant in Fukushima. The Japanese government has since begun to seriously consider how it can better prepare for another such natural disaster. In 2019, attention focused on the likelihood of a second tsunami being caused by a shift of the tectonic plates in the Nankai Trough. The Japanese government is warning that there is a considerable chance of the Nankai Trough causing further magnitude- 8 or -9 earthquakes and high tsunamis that would affect the entire south of Japan (the area from Tokyo area to Kyushu). Indeed, the chances of a magnitude- 7 earthquake hitting the Tokyo metropolitan area within next 30 years are as high as $70 \%$ (Cabinet Office, Government of Japan, n.d., see also Hurst 2019).

The 2011 tsunami was unprecedented in Japan, and the government has since learned from the experience. In 2013, the Ministry of the Environment announced "Disaster Measures Guideline for Pet Relief," Japan's first disaster guidelines for pets. Although it is not official legislation, local governments are expected to make disaster management plans according to guidelines. These 2013 guidelines strongly recommend the principle of Doko hinan (evacuation with pets).

H. Kajiwara, Surviving with Companion Animals in Japan, Palgrave Studies in Animals and Social Problems, https://doi.org/10.1007/978-3-030-49328-8_1 
However, the guidelines did not function well after the Kumamoto earthquake that occurred in 2016. The Ministry of the Environment consequently ordered that the guidelines be reviewed and revised. An investigative committee, consisting of ten experts and nine bureaucrats appointed by the Ministry of Environment, convened on August 2, 2017, September 27, 2017, and January 18, 2018. Brief summaries of each meeting are available to the public online (Ministry of the Environment, n.d.). In March 2018, the Japanese government released a revised edition of its conclusions entitled "Disaster Preparedness Guideline for Humans and Pets."

One of the reports that emerged from the hearings reveals the bureaucrats in the Ministry and Cabinet Office's concerns for and general outlook on disasters and pets. One government official commented at the meeting helps on September 27, 2017, with the following statement:

When we use the term "Doko hinan" [evacuation with pets] there is an assumption made by the owners of pets that they should be able to live together with their pets. Would not that imply that some kind of legal right is being established? This guideline should not be used for the claim of the rights. (Ministry of the Environment 2017a: 10)

Any personally identifiable information of the bureaucrat who spoke was not disclosed in the report, a common practice in Japan. Another anonymous bureaucrat commented:

If pets are accorded some kind of rights during an evacuation, their owners will insist that they be able to bring their pets with them to live in refugee accommodations. I think such an outcome should be avoided. (Ministry of the Environment 2017a: 18)

Dr. Shiro Muranaka, Vice President of Japan Veterinary Medical Association, and chairperson for the Review Meeting for the Revision of "Disaster Measures Guideline for Pet Relief," stated the following at the first meeting on August 12, 2017:

If the term "Doko hinan" [evacuation with pets] is used to justify the owners' rights, we will be in trouble. (Ministry of the Environment 2017b: 7) 
These comments provide some insight into the general outlook of the Japanese government in its reluctance to grant rights for pets when planning for evacuations. When guardians and their animals are required to evacuate during a disaster, the regulations regarding disaster response guidelines made by those in position of authority greatly affect future prospects. Moreover, these laws reflect how much society values humananimal relationships and animal rights. In other words, they reflect how society colonizes animals.

The 2018 version of the guidelines that has been updated title, "The Disaster Response Guidelines on Human and Pets" (Ministry of the Environment 2018), emphasizes the following four points. (i) The self-help by the guardians is basic in disaster response (ibid.: 7); (ii) evacuating with companion animals does not mean staying with companion animals in the refugee accommodation (ibid.: 5, 45); (iii) ensuring the place of refuge by the guardians themselves (ibid.: 17); (iv) pet support provided by the government agencies is not for the animal selves, but for the guardians as human victims (ibid.: 9). Thus, the guidelines declare the administrative support basically saves humans so guardians should not expect public support for pets. The owners are responsible for protecting themselves and their pets by self-help effort. Furthermore, it states that the measures against pets that are carried out by government agencies in the event of a disaster are not for the animals themselves, but from the viewpoint of saving the owners who are the victims. It could be said that the disaster management policy of Japan has become more anthropocentric since the 2011 tsunami and proceeding disasters.

As mentioned, these guidelines came about after the impact of the 2001 tsunami. On March 11, 2011, the northeast coast of Japan was struck by a huge tsunami that affected many people and their animals. This magnitude-9.0 earthquake, officially referred to as the Great East Japan Earthquake, is the largest in the recorded history of Japan (Japan Meteorological Agency 2013: 3). United States Geological Survey ranked this earthquake as the fourth largest earthquake in the history of world (USGS n.d.).

People with pets were refused entry to many communal shelters, and some were forced to abandon their pets. People unwilling to give up their pets often had to survive outside the emergency support frameworks established by government authorities and voluntary groups. Nine years after the disaster, that state of affairs continues to plague those who lost animals or who are struggling to maintain their relationship with their 
separated pet. After the Great East Japan Earthquake, many Japanese scholars began investigating the effects of a disaster. However, few studies have specifically considered the effects for guardians and their companion animals.

The interdisciplinary field known as Human-Animal Studies (HAS) explores the relationship between humans and other animals. Emerging in the 1990s, predominantly in the Western world, HAS is becoming accepted as a subfield by sociologists. Indeed, in 2002, animals and society was officially given status as a section within the American Sociological Association. DeMello (2012) defines HAS as "an interdisciplinary field that explores the spaces that animals occupy in human social and cultural worlds and the interactions humans have with them" (DeMello 2012: 2). One particular area of interest for those engaged in HAS is the power structure and cultural relations that define interactions between humans and other animals. HAS scholars regularly deal with other aspects pertaining to the experiences of humans living with animals. Research associated with HAS includes a broad range of disciplines such as psychology, veterinary medicine, and law. However, the research in this volume reports on how guardians and their companion animals experienced the aforementioned disaster from a sociological perspective.

Guardians and their companion animals face enormous difficulties in disasters, which raise a number of practical, social problems for policymakers and parties required to deal with humans and their animals whenever such crises occur. Various facets of disasters-those within and out of policymakers' control-can place strain on the otherwise significant relationship and bond between owners and pets. In addition to the outworking of the interrelation between owner and pet, the way society conceives the relationship itself often reflects previously unconsidered aspects of a society, such as the way power is distributed and embedded in the daily lives of its citizens.

The research discussed in this volume considers not only the relationships between guardians and companion animals, but also the relationships between guardians and other people, including government officials charged with looking after disaster victims. When discussing companion animals, this study pays particular attention to cats and dogs. While the author understands that many other kinds of animals build close relationships with humans, current society reflects that dogs and cats are primary companion animal due to their high prevalence and the strong intimacy between owner and pet. The research presented here explores the way 
practical support will be rendered when future disasters strike. The author hopes to provide a new way of thinking about the social consequences of how we deal with the human-animals nexus.

In many societies, companion animals are now accepted as social members. However, when disasters occur, companion animals and their guardians can suddenly be targeted, excluded, and even oppressed not only by the state, but also by well-meaning but uninformed voluntaries who are anxious to help those in need. The position afforded to companion animals and their guardians in times of stress reveals real mettle that binds together societies at a deeper level. It is a question about that in an inclusive society, who should be and how should be included even when we against difficulties.

The following three research questions are addressed in this volume:

(1) How did guardians and their companion animals survive the large disaster?

(2) Why was the relationship between guardians and their companion animals ignored during and after a disaster?

(3) What structures or mechanisms shaped the outcomes for animals and their guardians following the March 2011 tsunami?

Irvine (2004: 57-58) noted that since the 1990s, many working in this area have come to use the term "companion animal," in place of "pet," to encapsulate the emotional connection between the species, as well as humans' responsibility for their pets. This term is now common among academics in Japan. Irvine chooses to use "guardian" in her book, rather than the predominant term "owner." In the medical interview education class which the author teaches at Nippon Veterinary and Life Science University in Tokyo, "owner" implicates a proprietor of things, such as a car and an apartment, and thus, the term "family" or simply the personal name of the animal is recommended. However, Cudworth avoided the use of "guardian" in her research paper, emphasizing in her notes:

I avoid using the term 'guardian'. It does not reflect the material conditions of animal companions who are legally defined as property with minimal welfare safeguards in law. None of the human participants in my study used this term, describing themselves and others as 'owners.' (Cudworth 2018: 500) 
Notwithstanding these ongoing debates and the implications of each term, for the sake of convenience the author uses "companion animal" and "pet" interchangeably in this book, as with the terms "guardian" and "owner."

\subsection{Companion Animals in Japan}

Japan has a long history of keeping animals and has seen the rise of companion animals in both prevalence and personal importance in recent times. While several studies claim that the relationships between Japanese owners and their pets only strengthened throughout the 1990s, Japanese share a long and close history with dogs and cats. Inokuma writes that dogs crossed over to Japan from the Korean Peninsula and Nansei Islands (the chain of islands extending from southwest Kyushu to north Taiwan) after the Jomon period (14,000-300 BC). He also notes that a dog known as the "Japanese Ching" was kept inside as a pet by medieval aristocrats (Inokuma 2001: 32). It's likely that cats were introduced into Japan from the Asian continent during the Nara period (710-794 AD) as pets for the aristocracy (Nozawa and Takao 1981: 365).

Notwithstanding these historical exceptions, for many centuries animals were primarily kept for their practical value. Dogs were kept to protect households and to be an aid in hunting. Utsunomiya (1999: 108) states that cats also had a utilitarian value. Cats' ability to catch mice was important as rice, kimonos, books and other valuable possessions were often stored in wooden containers, and were thus susceptible to rodent contamination. Utsunomiya (1999: 108) reasons that cats consequently spread among the common people during the Muromachi period (1336-1573 AD).

With rapid urbanization in the twentieth century, the reasons for owning animals have changed. For instance, watchdogs had essentially disappeared by the end of the 1960s (Ishida 2013: 10). In line with theories about development and social convergence, Hamano (2013:22) argues that rapid economic growth in Japan after the 1950s produced the economic margin that would allow a shift away from keeping pets for instrumental reasons to having them for their consummatory value (i.e., for the joy found in the relationship itself). Many guardians have come to think of their companion animals as family members. In 2010, it was estimated that $34.3 \%$ of households in Japan included some kind of companion animal (Ministry of the Environment 2010). In this regard, 
it is interesting to note the findings of a survey conducted in 2017 that found that only $23.3 \%$ of Japanese households had children aged below 18 years old (Ministry of Health, Labour and Welfare 2018: 7). Japanese households containing companion animals outnumber those with younger children. Given the declining birth rate and aging population in Japan, it is likely that this gap will widen in the future. In an aging society with fewer children, some people are seeking to own companion animals for psychological reasons. The companion animal can be "an eternal child" for parents after their children have grown up and left home (Hamano 2013: 22).

Ozaki (2004) and Ozaki and Sakurai (2002) argue that a "pet boom" occurred from around 1990 with the number of dog registrations rising from 3.8 to 5.8 million between 1990 and 2000. The 1950 Rabies Prevention Law requires owners of dogs to register their animals with local governments within 30 days of acquiring the animal. Although owners do not always follow the guidelines, the government figures give us fair idea as to how the number of dogs is changing over time. The number of registered dogs has since continued to rise, and the figure stood at 6.9 million in 2009 (Ministry of Health, Labour and Welfare, n.d.). Figure 1.1 shows this rapid increase of dog registrations in the 1990s and early 2000s, further indicating Japan's increasing connection to dogs as pets, albeit since 2011 the number of registered dogs has generally decreased. Based on its own online survey, Japan Pet Food Association (2018: 18) estimated the number of dogs in Japan was approximately 8.9 million in 2018 . There is no official registration system for cats, but the Association's (2018: 18) estimate for cats was approximately 9.65 million in 2018 .

Although many accounts have substantiated the fact that the relation between Japanese and their dogs has been "very close" for some time, until the beginning of this century the majority of owners kept their dogs outside (Ozaki 2004: 27, 29). This perhaps reflected the ingrained cultural sense that the outside was in some way "dirty" or "contaminated," born out in the practice of removing footwear when entering homes and even offices. However, as the economy and consequently infrastructure developed in the 1970s and 1980s, seeing a rise of paved areas throughout Japan, the practice disappeared from public places and the sensitivity regarding what is clean and what is dirty has changed. Accordingly, although only $1 \%$ of apartments sold in the Tokyo metropolitan area in 1998 permitted pets, by 2007 the figure had risen 


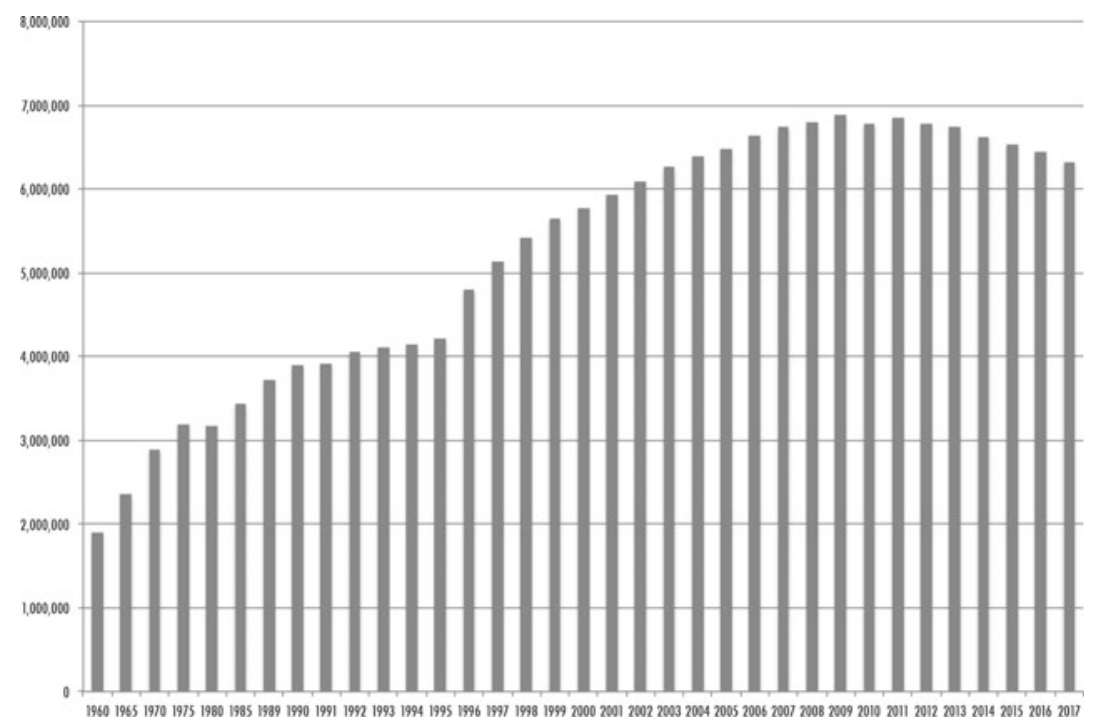

Fig. 1.1 Registered dogs in Japan, 1960-2017 (Source Compiled by the author from Ministry of Health, Labour and Welfare of Japan (n.d.). Inu no toroku tosu to yobo chusha tosu-to no nenji betsu suii (Showa 35-nen $\sim$ Heisei 29nendo) [Annual transition of the number of registration and vaccination of dogs, 1965-2017 fiscal year])

to $86.2 \%$ (Real Estate Economic Institute 2008: n.p., see also Real Estate Distribution Research Institute, Inc. 2008: n.p.). Moreover, Kakinuma (2008: 79-80) found that $80 \%$ of dogs are sleeping indoors, with $30 \%$ even sleeping in bed with their owner. According to one survey in 2018 found that $85.7 \%$ of owners were now keeping their pet dog indoors (Japan Pet Food Association 2018: 21).

A survey administered by a pet insurance company in 2018 found that dog owners spent an annual average of $J ¥ 480,000$ (approximately US\$4418) on the care of their pet, while cat owners were spending $J ¥ 230,000$ (approximately US\$2117). The survey also revealed that over $30 \%$ of pet owners spent more on grooming their animals than they did for themselves (Anicom Insurance, Inc. 2018: n.p.). The Yano Research Institute estimates that in 2018 the market size of the pet industry exceeded J¥1500 billion (about US\$13.5 billion), which includes veterinary clinics, pet shops, and other pet-related supplies (Yano Research 
Institute Ltd. 2018: n.p.). All this further corroborates that a strong attachment to pets has also been detected in Japanese society since the mid-1990s.

Another measure substantiating the shift toward pet ownership and attachment is the change in public language, as shown in Fig. 1.2. It illustrates that the number of newspaper articles in which the phrase "pet loss grief" (petto rosu) appeared in the title or text. Before 1995, there were no articles about pet loss grief in Japan's two major newspapers, Asabi and Yomiuri. After 1995, however, both newspapers began to publish articles on such grief, and the number of such articles has remained fairly constant since then.

The practice of dog-keeping in Japan today evident that the current enthusiasm for pet dogs continues to grow, as part of a much more extensive global phenomenon (Skabelund 2011: 182). Nevertheless, positive sentiments toward pets have not permeated all Japanese society. Indeed, in an effort to control animal population, a lot of dogs and cats are killed with carbon dioxide gas in Japan. There are "animal protection centers"

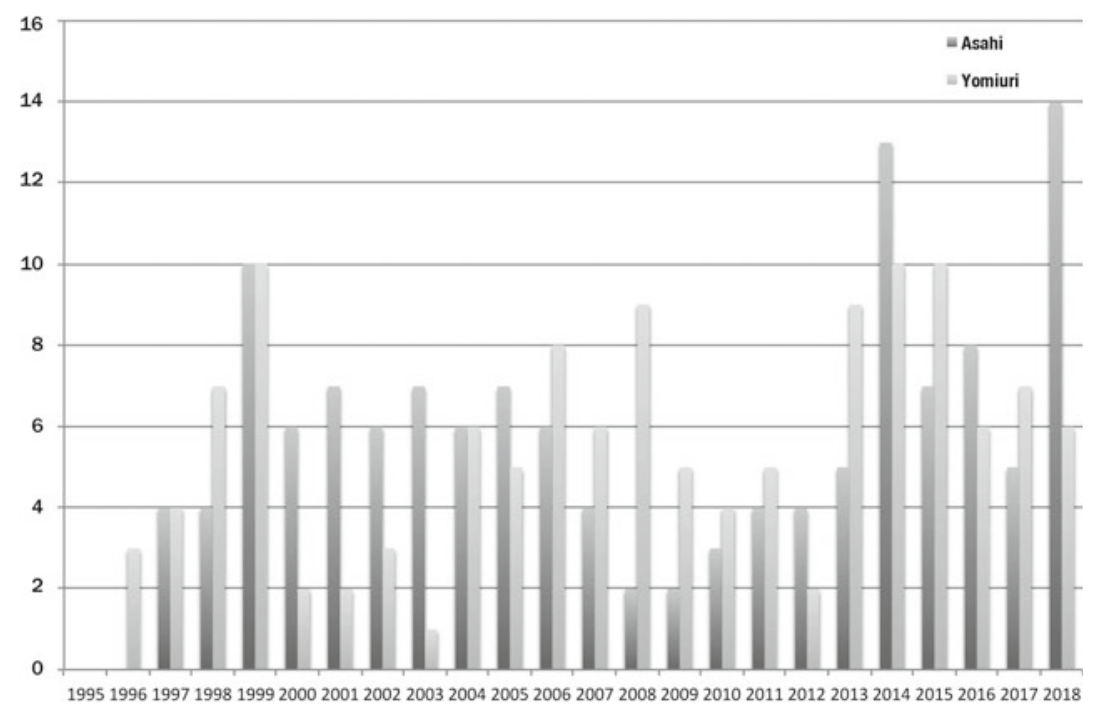

Fig. 1.2 Articles about pet loss grief (Source Compiled by the author from the Asahi Shinbun's database "Kikuzo II Visual" and the Yomiuri Shinbun's database "Yomidasu Rekishikan" from 1995 to 2018) 
(dobutsu bogo senta), "centers for the love and protection for animals" (dobutsu aigo senta) and "public health centers" (bokensho) in each of Japan's 47 prefectures. Though they have different names, they all function as animal control centers where lost or abandoned pets or ownerless dogs and cats are taken to. Only a few animals are returned to their owner, and some are adopted into a new family. But most are euthanized.

In June 2014, the Ministry of the Environment publicly announced an action plan to create a "society where humans and animals to live happily" (Ministry of the Environment 2014). One strategy was to increase the rate at which abandoned or ownerless pets would be adopted so that no animals would be killed. This indicates a top-down approach to societal acceptance and promotion of pets. Each year the Ministry of the Environment announces the statistics pertaining to the outcome of dogs and cats in the animal protection centers. Since these implemented government strategies, the number of animals put down has declined sharply since 2007 when 98,556 dogs and 200,760 cats were euthanized (Ministry of the Environment 2018). But still the numbers remain high, with 8362 dogs and 34,854 cats killed by gas in fiscal 2017 (Ministry of the Environment 2018; see Table 1.1). The author found that $194 \mathrm{dogs}$ and 316 cats were mysteriously lost in these statistics for some unknown reasons.

Though many of the local governments have procedures in place for adopting unwanted animals, in a lot of cases it is animal rescue activists who bring the animals to private shelters and try to find new foster families. Consequently, many of the more committed private shelters have found themselves overwhelmed by the number of animals (Ichijyodani 2017; NHK 2018; Ryukyu Shinpo 2018 August 25). Moreover, it should

Table 1.1 The disposal of animals taken to animal control agencies (2017)

\begin{tabular}{lrrr}
\hline & Dogs & Cats & Total \\
\hline Returned to owner & 12,286 & 316 & 12,602 \\
Adopted by new families & 17,669 & 26,651 & 44,320 \\
Euthanized by gas & 8362 & 34,854 & 43,216 \\
Total number of animals & 38,317 & 61,821 & 100,138 \\
Total number of animals by source & 38,511 & 62,137 & 100,648 \\
Missing in the count & 194 & 316 & 510 \\
\hline
\end{tabular}

Compiled by the author from Ministry of the Environment, Government of Japan (2018: n.p.). Inu neko no hikitoriri oyobi fusho dobutsu no shuyo jokyo [Taking custody of dogs and cats and containment situation of injured animals] 
be noted that the government's decision to implement a "zero-killing" policy has in some cases have misrepresented outcome. The local governments that aim for "zero-killing," such as Tokyo, do not include in their statistics dogs and cats that the animal control centers judged as too difficult for adoption. Thus, there are some animals have been intendedly excluded from the statistics. Several activists have claimed the animals that are unsuitable for adoption because of their age, disease, or aggressiveness have been left shut in the cages until they die.

Overall, the companion animals have come to occupy an increasingly important position in Japanese society. With that change has come a number of challenges which have not yet been adequately addressed. It continues to be the case that little attention has yet to be focused on the relationship between humans and their companion animals. The research reported below is an attempt to begin the huge effort that will be required to fill that lacuna.

\subsection{The March iI, 2OII, Earthquake}

The Great East Japan Earthquake (also known as 3.11 earthquake), a magnitude-9 earthquake, struck the Tohoku region in Japan at 14:46 on March 11, 2011. Thirty minutes to one hour later the coastal areas were hit by a huge tsunami. TEPCO's (Tokyo Electric Power Company) Nuclear Power Plant One (Daiichi) in Fukushima was seriously damaged from the tsunami and went into meltdown. Based on tsunami tracking data, Japan Meteorological Agency (2013: 4-7) concluded that the tsunami reached heights of up to 16 meters or more in Ofunato in the Iwate Prefecture (Fig. 1.3).

The earthquake and tsunami caused widespread damage along the coast of northeastern Japan, and many coastal cities and towns in Iwate, Miyagi, and Fukushima Prefectures were entirely destroyed. There were even some casualties as far away as Chiba Prefecture near Tokyo. The impacts on buildings were as follows: 121,990 houses completely destroyed, 282,900 houses partially destroyed, and 730,044 houses damaged (National Police Agency Emergency Disaster Security Headquarters 2019: 1). The official number of deaths resulting directly from the disaster is 15,897 people, and the number of missing persons is 2533 (National Police Agency Emergency Disaster Security Headquarters 2019: 1). According to the Reconstruction Agency (2018: 1), an additional 3701 people's lives were lost due to disaster-related deaths. 


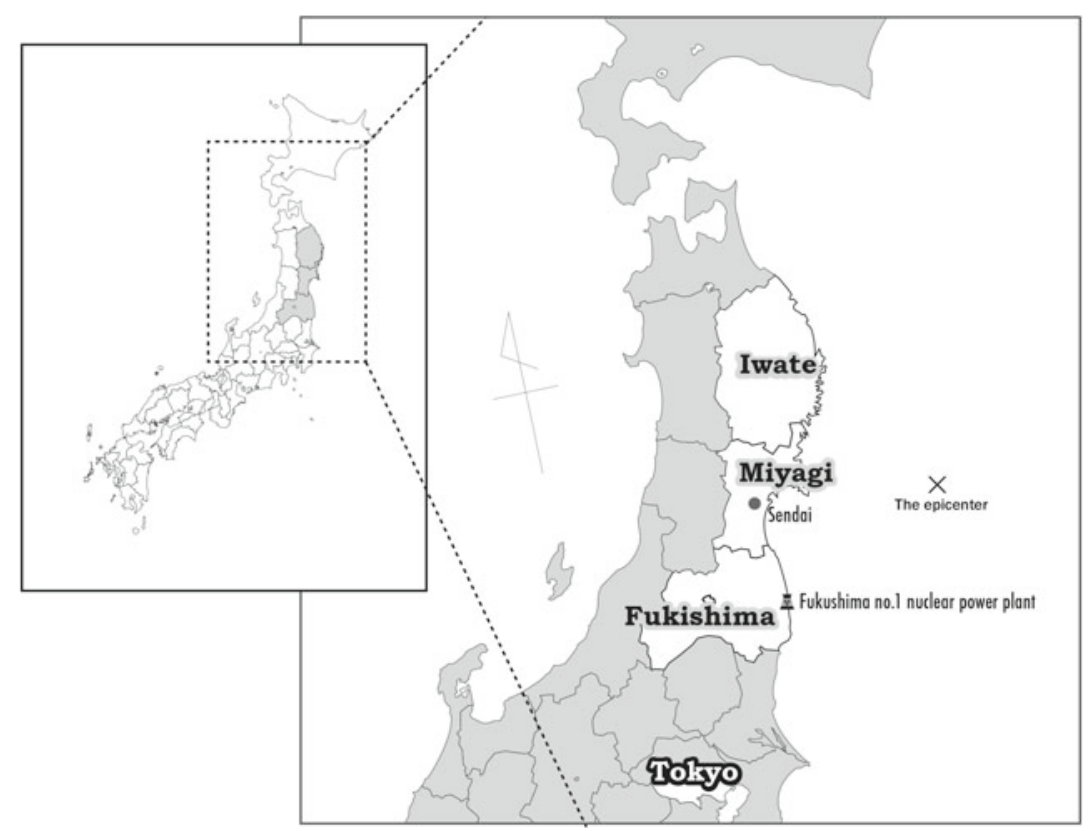

Fig. 1.3 Japan and the Tohoku region's three affected prefectures (Source Made by the author from Japan Meteorological Agency (2011: n.p.). The 2011 Great East Japan Earthquake: first report)

Journalist Hayakawa described that the disaster-related deaths caused by stress, exhaustion, and the worsening of preexisting illnesses due to evacuation (Hayakawa 2016: 123). Disaster-related deaths also include suicide as a result of depression while living in temporary accommodation.

Tokyo Electric Power Company (TEPCO) was running two nuclear power plants in Fukushima at the time of March 2011. Both nuclear power plants experienced blackouts as a result of the tsunami. At Nuclear Power Plant Two (Daini), all four nuclear reactors were shutdown. Nuclear Power Plant One went into complete meltdown. It contained six reactors of which the first, third, and fourth experienced hydrogen explosions. Although the second reactor did not explode, it emitted large amounts of radiation (National Diet of Japan Fukushima Nuclear Accident Independent Investigation Commission 2012: 25). The Nuclear and Industrial Safety Agency of Japan rated the urgency of the meltdown as 
a Level 7 incident on the International Nuclear and Radiological Event Scale (Ministry of Economy, Trade and Industry 2011: 1-2; see also International Atomic Energy Agency, n.d.). The Fukushima disaster is on par with that experienced at Chernobyl in 1986.

The number of animals affected by the tsunami is not clear. The Ministry of the Environment reported that 602 companion animals died in Iwate Prefecture while approximately 2500 died in Fukushima Prefecture. The number of such deaths in Miyagi Prefecture remains unknown (Ministry of the Environment 2013: 12).

Although the Japanese government did not provide residents with any details regarding the "accident" at the nuclear power plant, at 20:50 (local time) on March 11, 2011, an evacuation order was issued to inhabitants within a 3-kilometer radius of Nuclear Power Plant One. This evacuation zone gradually expanded to a 20-kilometer radius by 18:25 on March 12 (Hino 2015: 21). The Fukushima Prefectural Government did not allow residents to be evacuated with their companion animals (Kawamata 2014: 84); as a result, many animals were left behind in the radioactive contaminated areas.

On April 22, 2011, the evacuation zone (now the 20-kilometer radius) was sanctioned as highly restricted by the Japanese government, and barriers were erected around area. Consequently, it becomes extremely difficult for those owning animals to return home to rescue or simply to feed and water their animals. People who were caught entering the prohibited zones were subject to a fine of up to J¥100,000 (US\$920) or 30 days in national prison.

Ota (2012: 44) estimates that there were 5800 registered dogs and a similar number (if not more) of cats in the 20-kilometer radius of the nuclear power plant before the incident occurred. As some owners do not register their pets, the actual number of dogs and cats is certainly even higher. The Fukushima government claims it rescued 463 dogs and 545 cats from the evacuation zone between 2011 and 2015 (Fukushima Prefecture, n.d.; see also Itoh 2018: 15). It is estimated that the number of dogs and cats left behind would have been at least 10,000 and as high as 20,000 (Kawamata 2014: 85). That is, most companion animals were not rescued. There are few accurate statistics indicating the number of animals left behind or evacuated, and the number of animals that were born or died in the restricted zone since the disaster. However, statistics on farm animals are fairly accurate, because these animals are required to be registered with the government. Sato (2013: 24) reports that there 
were 3400 cows, 31,500 pigs, and 630,000 chickens. According to Sato, 630,000 chickens starved to death or were killed. 31,500 pigs too. But some pigs run away, after that they were euthanized. At the point of June 2012, 1700 cows death from hunger, illness, or accident. 975 cows were euthanized. 800 cows were rescued by farmer, 130 cows went wild. Although the number of cows does not add up correctly, it is deduced that this is because of the confusion in the disaster.

After the explosions at Nuclear Power Plant One, it became clear that the radioactive contamination had been spread over more than 20 kilometers to the east-northeast by the wind; hence, the 20-kilometer radius evacuation zone was not enough. Although the System for Prediction of Environmental Emergency Dose Information (SPEEDI) had calculated this spread of pollution and had immediately informed the government, the information was not made public. As a result, many people initially fled in this direction and were further exposed to radiation. On April 16, 2012 , the government then redefined the evacuation area, designating three zones with differing procedures for evacuees to return home. The first zone included areas in which the level of radioactivity was judged to be 20 millisieverts per year, and residents originally from this zone could prepare to return home. The second zone included areas where the level was judged to be $20-50$ millisieverts per year and the return of residents was restricted. The third zone included areas at over 50 millisieverts per year and a return home resettlement was judged to be impossible a long period of at least over 5 years. The first zone "Zone in preparation for the lifting of the evacuation order [Hinan shiji kaijo junbi kuiki]" and second zones "Restricted residence area [Kyoju seigen kuiki]" included a village 30 kilometers to east-northeast from the Fukushima No. 1 nuclear power plant. In these areas, the government did not allow residents to stay overnight at home in principle, but allowed them to return home only during the day. The government prohibited entry the third zone "Difficult-to-return zone [Kikan konnan kuiki]," in principle. If the residents or the employees of radioactive decontamination companies go into the areas with permission, they were required to wear protective clothing and carry a radiation dosimeter.

In April 2017, the national government lifted all evacuation orders for residents with property in zones one and two that have been judged safe and level of radioactivity under 20 millisieverts per year. Many Japanese citizens, Japanese and international experts and media question this decision because the worldwide safety standards of radiation exposure are 
1 millisievert per year-a standard that is ironically observed in other parts of Japan. For example, a human rights specialist of United Nations, Baskut Tuncak reported that on October 25, 2018, a return of residents to the areas of 20 millisieverts per year is underway in Fukushima, which may have a serious impact on the health of the residents. He expressed a serious concern and urged the Japanese government to stop to let returning evacuees, especially those of children and reproductive age for women (The Office of the High Commissioner for Human Rights (UN Human Rights) 2018: n.p.). While the government has decontaminated the houses of inhabitants, the radioactive contamination in mountainous areas and rivers has not been addressed, leaving nearby residential areas at risk. Consequently, most young people and families with children have not returned to their original homes. Eight years after the nuclear accident, only $23.2 \%$ of the former residents have returned to zones one and two (Kahoku Shimpo 2019: n.p.). Newspaper Kahoku Shimpo (ibid.: n.p.) also found that in Namie, a town less than 20 kilometers from Fukushima Nuclear Power Plant One, only $6.2 \%$ of the residents have returned to live in their homes.

The number of people from Fukushima Prefecture who continue to live in temporary evacuation housing is 42,480 as of March 2019 (Fukushima Prefecture Disaster Countermeasures Headquarters 2019: 1). Those figures do not include individuals who have acquired a new house independently of government assistance and those who have found accommodation in the public housing for victims built by local governments. Public housing, unlike simple and cheap structure temporary housing, can live permanently, but some people who want to return to their original homes someday also live there. They think they are still "evacuated." Also, there are no accurate statistics about people who fled themselves to other prefectures. Without actual figures, it remains difficult to ascertain the number of people impacted, and the challenging conditions faced by nuclear refugees. The national and prefectural governments along with the Tokyo Electric Power Company (TEPCO) have been trying to decrease the number of people identifiable as "refugees" in order to reduce the amount of compensation for which they might be held responsible. TEPCO is now paying J¥100,000 (US\$920) per month to each resident of the affected areas as compensation, but stop paying even that small amount when the restrictions are lifted on a person's property. To put it in perspective, the reparations are less than a starting salary for a college or university graduate J¥183,700 (US\$1738) 
(National Personnel Authority 2019: 6). The government was aiming to formally declare that it has achieved "zero refugees" by the time of the Tokyo Olympics in 2020, although the Olympics were not held due to the global pandemic of COVID-19. But while the number of refugees may technically decrease, the high levels of radioactivity caused by the nuclear disaster continue to pose challenges that ought to be recompensed. For instance, with the prevalence of cryptorchidism among children increased 13.4\% nationwide following the Fukushima nuclear explosions (Murase et al. 2018: 67).

The government and TEPCO now state that they will complete the decommissioning of the nuclear reactors in Fukushima within the next 40 years. However, there is still no known means of neutralizing nuclear reactors after they have exploded, and some experts are suggesting that it may take over 100 years until the nuclear reactors can be fully decommissioned. It is likely that the Great East Japan Earthquake will continue to pose issues in Japan, particularly as it pertains to the evacuation and rehousing of residents, for some time into the future.

\subsection{Disasters AND Animals}

The grief of those who lose their pets in the midst of disaster is often overlooked and ignored by others around them. Doka defines such grief which is not recognized by others as "disenfranchised grief" (Doka 2002: 11). Even though one family member may consider their pet to be an equal part of the family, it is often the case that other members of the same family afford the pet a much lower status, and are thus less affected by the pet's death. Redmalm (2015: 32) argues that the problem is not simple or straightforward, pointing to the ambiguity generated by pet grief that often resides as "liminal grief - as grief simultaneously inside and outside the margin." In any case, the sense of isolation which follows can become a serious psychological burden for many pet owners who have lost or otherwise become separated from their pets during and after a disaster. Indeed, several psychologists have conducted quantitative investigations to this end. Zottarelli (2010), for instance, suggests that pet loss impacts negatively on the ability of their owners to respond in a safe, timely, or effective fashion during and after a disaster. And the adverse consequences endure; indeed, Hunt et al. (2008), for instance, found that pet loss or forced abandonment slowed the process of recovering from a disaster. Other research Hunt involved has pointed the benefits 
that would flow from allowing pets and owner more easily to evacuate together (Hunt et al. 2012). Moreover, animals could be a protective factor rather than a risk factor during disasters, facilitating the development of "disaster resilience" in humans (Thompson 2013; Thompson et al. 2014). Trigg et al. (2015) questionnaire survey provided another perspective on the pet-owner relationship by investigating the interactions between humans and animals during calamity in Australia. They suggest that having an understanding of differences in pet-owner closeness can improve the effectiveness of rescue teams when disasters occur (see also O'Dwyer and Thompson 2018; Thompson et al. 2017).

In her quantitative investigation, Yamazaki (2015) analyzes factors influencing the evacuation behavior of pet owners, summarizing their need for support. She indicates the importance of education and preparation before an evacuation. Although her study is highly significant as pioneering research, it overlooks the broader social impact when a nuclear disaster occurs. Potts and Gadenne (2014) provide an extensive qualitative account from experts in the area of animal protection, rescue and welfare, as well as the views of pet owners in the context of the 2011 earthquake in Christchurch, New Zealand. The research concludes that while traumatic experiences often deepened the connection humans felt with their animals, the responses of emergency management services tended to be anthropocentric. There is research further investigating the decision-making process regarding and responding to pets and animals in disaster, and Irvine (2009) concludes that the vulnerability of animals is constructed by our "thinking." In her book Animals and the Fukushima Nuclear Disaster (2018), Itoh discusses the Japanese government's policies affecting animals and the actions of volunteer animal rescue groups of the Fukushima nuclear disaster. This book, however, focuses on the personal experiences of guardians, the relationship with their companion animals, and the social and political structures that shape their treatment during and after the Great East Japan Earthquake.

Reflecting disaster realities, the Pet Evacuation and Transportation Standards (PETS) Act of 2006 was passed in the United States following Hurricane Katrina in 2005 (United States Government 2006 Public Law 109-308). Known as "PETS Act," the act ensures that preparations and operational plans address the needs of individuals with household pets and service animals during and following local and state emergencies. Leonard and Scammon (2007) provide an interesting review on changes in societal views of pets that may have contributed to the enactment of the PETS 
Act. Through interview surveys carried out in Texas following Hurricane Harvey in 2017, Glassey (2018) found that the PETS Act and the lessons of Hurricane Katrina had a positive effect for companion animals in the disaster response.

Western scholars have turned their interest toward the animal rescue activities the Great East Japan Earthquake disaster in Japan. For example, through qualitative research, both Ahonen (2012) and Mattes (2016, 2018 ) illustrate the difficulties the animal rescue volunteers faced and their ongoing struggles due to Japan's lack of well-established NGOs, like Humane Society in the United States. It is important to note that the aforementioned studies and those investigating Japan's response to the 3.11 earthquake written from a North American perspective or Western context. For that reason, it is useful to consider how the relationship between guardians and their companion animals is changing in the nonWestern world, written from a non-Western perspective. It is helpful to consider enduring impact of traditional cultural outlooks and the extent to which affluence and the spread of urban lifestyles are likely to change the way people view and treat animals in other societies. Thus, there has been little qualitative study done concerning disaster and animals in the evolving sociocultural context of Japan. Therefore, it can be said this volume is a pioneering research in this field.

There are a few Japanese studies investigating the impact of disasters that ought to be mentioned. However, there are not many studies that pay attention to guardians and their companion animals during such calamities. Studies considering disasters began in earnest after the Great Hanshin-Awaji Earthquake that hit western Japan in 1995. Yamaji (2013), whose previous work looks into reconstruction post-disaster from a gendered point of view, investigates the process of and problems associated with pets permitted to live in public housing allowed, which was authorized after the Great Hanshin-Awaji Earthquake. When they built the temporary public housing, Hyogo Prefecture and Kobe City initially banned residents to keep their pets. However, many demanding letters were posted to the government's offices from the Japan Anti-Vivisection Association (JAVA) and La Foundation Brigitte Bardot, an animal protection foundation in France. The Governor of Hyogo accordingly permitted keeping companion animals in the public housing. However, there was limited housing and space for disaster refugees, even less so if animals were to be kept there, and many temporary housing complexes were only built two years after the earthquake (Yamaji 2013: 4-5). Yamaji (2013: 
1) concludes that providing pet-friendly public housing was needed in the early stages of the Great East Japan Earthquake. However, similar to the 1995 earthquake, problems occurs whereby there was limited or delayed public housing after the 2011 earthquake disaster, which is clarified in Chapter 3.

There is also research and fieldwork specific to the Great East Japan Earthquake in sociological terms. However, again, there are few scholars who are paying attention to the relation between human and companion animals. Although the following two records are not research papers per se, they offer important insight on this particular topic. The first record was published by the Ministry of the Environment (2013) reporting the suffering situation endured by animals in disasters, and how Japanese national and prefectural governments responded. The second record is a special issue of Chikusan no Kenkyu (Sustainable livestock production and human welfare), a magazine that specializes in stock raising. ${ }^{l}$ The feature gives accounts on how the veterinarians, administrative officers, and volunteers coped with the suffering animals from the 3.11 earthquake (Chikusan no Kenkyu 2014).

The Great East Japan Earthquake certainly was not the last large-scale disasters the national government deemed "major disaster." Subsequent disasters include the 2016 Kumamoto earthquake in the Kyushu region in south Japan; the 2018 floods in western Japan; and the 2018 Hokkaido Eastern Iburi earthquake in north Japan. But still, findings on the impact of and relationship between disaster and animals have not progressed. Although Kato's (2017a; see also 2017b) work provides a good exception to this status quo, Kato, an associate professor at Kyushu University of Health and Welfare, went to Mashiki Sports Park shelter immediately after the 2016 Kumamoto earthquake to conduct his research. He became and continues to be an ongoing supporter for the guardians who evacuated with companion animals as a supporter, and he wrote about his activity as an ethnography. Kato carefully describes the course of the situation chronologically-starting from the moment of the disaster's impact and the period of confusion that followed. According to him, guardians could stay with their pets in a refuge during the confusion phase. However, when order and regulations were being establishing in the refuge, the rule "No pets allowed inside" was imposed and an animal shelter was established. Kato continued taking the photographs of the companion animals and held the photo exhibition in support of the guardians. Kato's paper merits the following: He observes changes in the modes of treatment of 
pets in an evacuation area immediately after an earthquake has occurred. In addition, his study provides a good example of action research through supporting the guardians and their companion animals. Nevertheless, as Kato states that the discussion is a preliminary one, progress in his study regarding this event is expected.

Thus, there are very few studies that conduct full-scale fieldwork and that analyze the data regarding a disaster and companion animals in Japan, particularly the Great East Japan Earthquake, sociologically. The aforementioned studies that explore animals in disaster in Japan are not recognized in global academia, but they are still worthy for interest's sake. This book endeavors to develop such new field. This study makes significant impact on human-animal studies in this context of disasters in Japan, using empirical research and applied critical realism, which will be detailed in Chapter 8. This research deserves reference as a record of humans and animals during the biggest nuclear disaster in the world since Chernobyl.

As discussed, disasters in Japan continue to exist beyond the Great East Japan Earthquake. Moreover, the negative effects of the earthquake and aforementioned flooding in 2018 continue. Forest fires and largescale hurricanes occur frequently around the world due to climate change. This research was originally conceived as a $\mathrm{PhD}$ project that aimed to contribute to the field of HAS and sociology by considering the way Japan, a highly developed Asian society, has responded to the plight of pet owners on a social and legislative scale following a major disaster.

\subsection{OVERVIEW OF THE RESEARCH}

This chapter provided a brief background of the empirical research in this volume by describing the position of companion animals in contemporary Japan and the context of the 3.11 earthquake and tsunami. Chapter 2 explains the methods and procedures of the research.

This book is composed of four parts. Following the introduction and methodology in Part I, Part II, which comprises Chapters 3 and 4, describes the experience of guardians and their companion animals in the tsunami-affected areas in Iwate and Miyagi prefectures. Chapter 3 gives a detailed account of Mr. Ryoichi Suzuki's experience of surviving the tsunami with his wife and their small dog, Baron. Chapter 4 goes on to describe the actions of a further nineteen guardians. Based on their behavior during the evacuation, the author explores the quality of the 
relationship between the guardians and their companion animals before, during, and after the disaster.

Part III, which includes Chapters 5-7, depicts the experiences of guardians and their companion animals in the nuclear disaster-affected areas in Fukushima Prefecture. Chapter 5 relates the life story of Ms. Hitomi Sato, who lost her dog and one of her cats during evacuation from a nuclear disaster. Chapter 6 provides an account of the actions taken by 34 guardians affected by a nuclear power plant accident. Their behavior during the evacuation was considerably more complicated than in the other tsunami areas, and so Chapter 7 explores some factors of that complexity.

Part IV, composed of Chapters 8-10, seeks to explain the social phenomena visible in the testimonies presented in Parts I and II by focusing on causal mechanisms and structures. In the framework of critical realism, "abduction" and "retroduction" are crucial tools that allow for a number of inferences to be made. These two inference methods are explained in detail in Chapter 8. In that chapter, the author highlights some of the deep structures or mechanisms that shape events in the world-what is called the "real domain" in critical realism. The basic stance of Human-Animal Studies (HAS), which has developed over the past 30 years in academic world, particularly in the Western world, has not been rooted in Japan. The relationship between humans and animals in Japanese society is supported by the ambiguous notions of "The Love and Protection for Animals [doubutsu aigo]." This concept prioritizes economic logic over animal rights. The dynamics of structures that ignored and oppressed the relationship between guardians and pets in a disaster is showed in Fig. 8.1. Chapter 9 discusses the expected arguments that might emerge with regard to having bonding rights for guardians and their companion animals in the future. The guardian's behavior cannot be understood without the assumption that there is a primitive tie of life that transcends species. Moreover, that primitive interspecies tie is defined as the notion of "bonding." Given that general understanding, the author suggests that it is therefore necessary to establish "bonding rights" for social change. Finally, Chapter 10 provides a conclusion, underlining this book's significance and pointing toward future research and policy discussions. 


\section{Note}

1. "Chikusan no Kenkyu" literally means "The study of animal husbandry." However, the magazine is published with an English name "Sustainable livestock production and human welfare."

\section{REFERENCES}

\section{Literature IN ENGLISH}

Ahonen, P. (2012). Animal lovers, bridge-builders, and supervising watchdogs: Framing and civil society construction by Japanese pro-animal organizations in the Kansai and Tokyo areas (Master's thesis). University of Turku.

Cudworth, E. (2018). 'Now, where were we?' The highs and lows of hunting data with a research pack. Journal of Sociology, 54(4), 488-503.

DeMello, M. (2012). Animals and society: An introduction to human-animal studies. New York: Columbia University Press.

Doka, K. J. (2002). Disenfranchised grief: New directions, challenges, and strategies for practice. Champaign, IL.: Research Press.

Glassey, S. (2018). Did Harvey learn from Katrina? Initial observations of the response to companion animals during Hurricane Harvey. Animals, 8(4), 47.

Hayakawa, M. (2016). Increase in disaster-related deaths: Risks and social impacts of evacuation. Annals of the ICRP, 45(2_suppl), 123-128.

Humane Society of the United States. https://www.humanesociety.org/.

Hunt, M., Al-Awadi, H., \& Johnson, M. (2008). Psychological sequelae of pet loss following Hurricane Katrina. Anthrozoös, 21(2), 109-121.

Hunt, M. G., Bogue, K., \& Rohrbaugh, N. (2012). Pet ownership and evacuation prior to hurricane irene. Animals: An Open Access Journal from MDPI, 2(4), 529-539.

Hurst, D. (2019, June 12). 'This is not a "what if" story': Tokyo braces for the earthquake of a century. The Guardian. Retrieved December 13, 2019, from https://www.theguardian.com/cities/2019/jun/12/this-is-nota-what-if-story-tokyo-braces-for-the-earthquake-of-a-century.

International Atomic Energy Agency. (n.d.). Fukushima nuclear accident. Retrieved August 10, 2019, from https://www.iaea.org/newscenter/focus/ fukushima.

Irvine, L. (2004). If you tame me: Understanding our connection with animals. Philadelphia, PA: Temple University Press.

Irvine, L. (2009). Filling the ark: Animal welfare in disasters. Philadelphia, PA: Temple University Press.

Itoh M. (2018) Animals and the Fukushima nuclear disaster. The Palgrave Macmillan Animal Ethics Series. New York: Palgrave Macmillan. 
Japan Meteorological Agency (JMA). (2011). The 2011 Great East Japan earthquake: First report. Retrieved December 21, 2019, from https://www.jma. go.jp/jma/en/News/2011_Earthquake_01.html.

Japan Meteorological Agency (JMA). (2013). Lessons learned from the tsunami disaster caused by the 2011 Great East Japan earthquake and improvements in JMA's tsunami warning system. Retrieved June 17, 2019, from https://www.data.jma.go.jp/svd/eqev/data/en/tsunami/ LessonsLearned_Improvements_brochure.pdf.

Leonard, H. A., \& Scammon, D. L. (2007). No pet left behind: Accommodating pets in emergency planning. Journal of Public Policy \& Marketing, 26(1), $49-53$.

Mattes, S. (2016). The shared vulnerability and resiliency of the Fukushima animals and their rescuers. In M. S. Chaiken \& M. Companion (Eds.), Responses to disasters and climate change: Understanding vulnerability and fostering resilience (pp. 103-112). Boca Raton, FL: CRC Press.

Mattes, S. M. (2018). Animals left behind: Multispecies vulnerability in post-3-11 Japan (Doctoral dissertation). Michigan State University.

Murase, K., Murase, J., Machidori, K., Mizuno, K., Hayashi, Y., \& Kohri, K. (2018). Nationwide increase in cryptorchidism after the Fukushima nuclear accident. Urology, 118, 65-70.

O'Dwyer, L., \& Thompson, K. (2018). Attachment, bushfire preparedness, planning, and response among Animal Guardians: A South Australian case study. PLoS currents, 10. Retrieved October 30, 2018, from https://www.ncbi.nlm. nih.gov/pmc/articles/PMC6097849/.

Potts, A., \& Gadenne, D. (2014). Animals in emergencies: Learning from the christchurch earthquakes. Christchurch, New Zealand: Canterbury University Press.

Redmalm, D. (2015). Pet grief: When is non-human life grievable? The Sociological Review, 63(1), 19-35.

Skabelund, A. H. (2011). Empire of dogs: canines, Japan, and the making of the modern imperial world. Ithaca, NY: Cornell University Press.

The Office of the High Commissioner for Human Rights (UN Human Rights). (2018). Japan must balt returns to Fukushima, radiation remains a concern, says UN rights expert. Retrieved December 25, 2019, from https://www.ohchr.org/en/NewsEvents/Pages/DisplayNews. aspx?NewsID=23772\&LangID=E.

Thompson, K. (2013). Save me, save my dog: Increasing natural disaster preparedness and survival by addressing human-animal relationships. Australian Journal of Communication, 40(1), 123-136.

Thompson, K., Every, D., Rainbird, S., Cornell, V., Smith, B., \& Trigg, J. (2014). No pet or their person left behind: Increasing the disaster resilience 
of vulnerable groups through animal attachment, activities and networks. Animals, 4(2), 214-240.

Thompson, K., Trigg, J., \& Smith, B. (2017). Animal ownership among vulnerable populations in regional South Australia: Implications for natural disaster preparedness and resilience. Journal of Public Health Management and Practice, 23(1), 59-63.

Trigg, J., Smith, B., \& Thompson, K. (2015). Does emotional closeness to pets motivate their inclusion in bushfire survival plans? Implications for emergency communicators. Australian Journal of Emergency Management, 30(2), 24-30.

United States Geological Survey (USGS). (n.d.). 20 Largest earthquakes in the world. Retrieved June 12, 2020, from https://www.usgs.gov/natural-haz ards/earthquake-hazards/science/20-largest-earthquakes-world?qt-science_c enter_objects $=0 \#$ qt-science_center_objects.

United States Government. (2006). Pets Evacuation and Transportation Standards Act [Pdf file]. Retrieved August 25, 2016, from https://www.congress. gov/109/plaws/publ308/PLAW-109publ308.pdf.

Yamazaki, S. (2015). A survey of companion-animal owners affected by the east Japan great earthquake in Iwate and Fukushima prefectures, Japan. Anthrozoös, 28(2), 291-304.

Zottarelli, L. K. (2010). Broken bond: An exploration of human factors associated with companion animal loss during Hurricane Katrina. Sociological Forum, 25(1), 110-122.

\section{LITERATURE IN JAPANESE}

Anicom Insurance, Inc. (2018). Mainenkorei! Petto ni kakeru nenkan shishutsu chosa (2018-nen) [Annually! Annual expenditure survey on pets 2018]. 5 August 2019. https://www.anicom-sompo.co.jp/news/2018/news_0190 315.html.

Cabinet Office, Government of Japan [Naikakufu]. (n.d.). Jishin saigai sotei sa reru daikibo jishin [Earthquake disaster, large earthquake that are expected]. Retrieved June 16, 2019, from http://www.bousai.go.jp/kyoiku/hokenkyou sai/jishin.html.

Chikusan no Kenkyu [Sustainable Livestock Production and Human Welfare]. (2014). Special issue: Higashinihon daishinsai ka no dobutsu tachi to ningen no kiroku-konpanion animaru hen [The record of the animals and human beings under the Great East Japan earthquake-Volume of companion animals ], 68(1). Tokyo: Yokendo.

Fukushima Prefecture. (n.d.). Keikai kuiki, kikan kon'nan kuiki-nai ni okeru hogo katsudo no kekka ni tsuite [About result of protection activity in the restricted areas and the difficult-to-return zones] [Pdf file]. Retrieved August 10, 2019, from https://www.pref.fukushima.lg.jp/uploaded/attachment/150572.pdf. 
Fukushima Prefecture Disaster Countermeasures Headquarters [Fukushimaken saigai taisaku honbu]. (2019). Heisei 23-nen Tohoku chiho Taibeiyo oki jishin ni yoru higai jokyo soku ho (dai 1756-po) [Immediate report on damage caused by the 2011 off the Pacific coast of Tohoku Earthquake (1756th report)] [Pdf file]. Retrieved August 10, 2019, from https://www.pref.fukushima.lg.jp/upl oaded/life/438691_1107339_misc.pdf.

Hamano, S. (2013). Katei Dobutsu to no Tsukiai [Relations with the family animals]. In O. Ishida, S. Hamano, M. Hanazono, \& A. Setoguchi (Eds.), Nibon no Doubutsu Kan: Hito to dobutsu no Kankei Shi [Japanese attitudes toward animals: A history of human-animal relations in Japan] (pp. 19-35). Tokyo: University of Tokyo Press.

Hino, K. (2015). Genpatsu hinan no hassei to katei [The generation and process of an nuclear evacuation]. In Kanseigakuindaigaku saigai fukko seido kenkyujo [Research Institute for Disaster Recovery System, Kansei Gakuin University], Higashinihon daishinsai shien zenkoku nettowaku (JCN) [The Great East Japan Earthquake Support National Network (JCN)] and Fukushima no kodomo-tachi o mamoru horitsuya nettowaku (SAFLAN) [Lawyers Network to Protect Fukushima Children (SAFLAN)] (Ed.), Genpatsu hinan bakusho [Nuclear evacuation white paper] (pp. 19-30). Kyoto: Jinbunshoin.

Ichijodani, K. (2017). Hogo dantai wa panku sunzen! Fukona neko o ippiki demo herasu tame ni ichiban taisetsuna koto [The protection groups are going to burst! The most important thing to reduce even one unhappy cat]. Sarai.jp. Retrieved August 10, 2019, from https://serai.jp/living/167944.

Inokuma, H. (2001). Inu no Dobutsu Gaku: Animaru Saiensu 3 [Zoology of domestic dogs: Animal science 3]. In Y. Hayashi \& E. Sato (Eds.). Tokyo: University of Tokyo Press.

Ishida, O. (2013). Josho Dobutsu-kan no Keifu [Introduction: The genealogy of attitudes toward animals]. In O. Ishida, S. Hamano, M. Hanazono, \& A. Setoguchi (Eds.), Nibon no Doubutsu Kan: Hito to dobutsu no Kankei Shi [Japanese attitudes toward animals: A history of human-animal relations in Japan] (pp. 1-16). Tokyo: University of Tokyo Press.

Japan Pet Food Association [Ippan shadanhojin pettofudo kyokai]. (2018). Heisei 30-nen (2018-nen) zenkoku inuneko shiiku jittai chosa shuyo shibyo samari [National breeding survey of dog and cats 2018: Summary of key indicators]. 28 July 2019. https://petfood.or.jp/data/chart2018/3.pdf.

Kahoku Shimpo. (2019, April 12). Fukushima: hinan kaijo 9 kuiki no kyojuritsu 23. 2-Pasento tomari koreikaritsu wa kosuijun [Fukushima: Residential rate in 9 areas for evacuation cancellation only $23.2 \%$ high aging rate]. Retrieved August 10, 2019, from https://www.kahoku.co.jp/tohokunews/ 201904/20190412_63016.html.

Kakinuma, M. (2008). Hattatsu shinrigaku kara mita kainushi to inu no kankei hito no migattena yokyuni honrosareru inu [The relationship between owner 
and dog from the point of view in developmental psychology: Dogs who are tossed about by the selfish demands of human]. In Y. Hayashi, Y. Mori, F. Akishinonomiya. K. Ikeya, \& T. Okuno (Eds.), Petto to Shakai: Hito to dobutsu no kankeigaku 3 [Pets and society: The study of human animal relations 3] (pp. 79-99).Tokyo: Iwanami shoten.

Kato, K. (2017a). Heisei 28-nen Kumamoto jishin ni okeru “petto doko hinan” ni kansuru yobi-teki kosatsu: Mashiki-machi sogo undo koen hinanjo no jirei yori [Preliminary considerations on "pet evacuation" following the Kumamoto earthquake in 2016: A case study on the shelter in Mashiki Town General Sport Park]. Kyushu hoken fukushi daigaku kenkyu kiyo [Journal of Kyushu University of Health and Welfare], 18, 33-44.

Kato, K. (2017b). Heisei 28-nen Kumamoto jishin hisai-chi ni okeru "hito to petto no <gensai>" ni kansuru jissen-teki kenkyu: Kumamoto ken Mashikimachi no kasetsu danchi no jirei o chushin ni [Practical research on "disaster risk reduction of people and pets" in the area affected by the 2016 Kumamoto earthquake: Focusing on the case of temporary housing complex in Mashiki Town, Kumamoto Prefecture]. Kenkyu katsudo hokoku-sho [Research/Activity Report], 43-56 [Pdf file]. Retrieved October 19, 2018, from http://id.nii. ac.jp/1147/00001325/.

Kawamata, J. (2014). Shinsai Oyobi Genpatsu Jiko Niyoru Fukushima Ken Juishi-kai de no Taio [Response of the Fukushima Veterinary Medical Association during an earthquake disaster and nuclear plant accident]. Chikusan no Kenkyu [Sustainable Livestock Production and Human Welfare], 68(1), 83-91.

Ministry of Economy, Trade and Industry [Keizaisangyosho]. (2011, April 12). News Release Tohoku chiho Taiheiyo oki jishin ni yoru fukushima daiichigenshiryoku hatsudensho no jiko toraburu ni taisuru INES (kokusai genshiryoku hoshasen jisho hyoka shakudo) no tekiyo ni tsuite [Application of INES (International Nuclear and Radiological Event Scale) for accidents and troubles at the Fukushima Daiichi Nuclear Power Station caused by the Tohoku Pacific Ocean Earthquake]. [Pdf file]. Retrieved August 10, 2019, from https://www.mhlw.go.jp/stf/shingi/2r9852000001 eap9-att/2r9852000001eax7.pdf.

Ministry of the Environment, Government of Japan [Kankyosho]. (n.d.). Saigaiji ni okeru petto no kyugo taisaku gaidorain no kaitei to ni kakaru kentokai Giji gaiyo [The proceedings summary of review meeting for the revision of “Disaster Measures Guideline for Pet Relief”]. 16 June 2019. https://www. env.go.jp/nature/dobutsu/aigo/2_data/saigai_guide.html.

Ministry of the Environment, Government of Japan [Kankyosho]. (2010). Dobutsu aigo ni kansuru seronchosa no gaiyo [The summary of opinion poll about animal protection 2010 October]. 3 August 2019. http://www.env.go. jp/press/files/jp/16451.pdf. 
Ministry of the Environment Government of Japan [Kankyosho]. (2013). Higashinibon daishinsai ni okeru hisai dobutsu taio kiroku-shu [The chartulary of response to the affected animals in the Great East Japan Earthquake]. [Pdf file]. Retrieved August 10, 2019, from https://www.env.go.jp/nature/ dobutsu/aigo/2_data/pamph/h2508c/full.pdf.

Ministry of the Environment Government of Japan [Kankyosho]. (2014). Hito to dobutsu ga shiawase ni kurasu shakai no jitsugen purojekuto akushonpuran [Action plan for realizing a society where people and animals to live happily] [Pdf file]. Retrieved August 10, 2019, from https://www.env.go.jp/nature/ dobutsu/aigo/project/download/actionplan_H26.pdf.

Ministry of the Environment, Government of Japan [Kankyosho]. (2017a). Saigai-ji ni okeru petto no kyugo taisaku gaidorain no kaitei to ni kakaru dainikai kentokai Giji gaiyo [The proceedings summary of review the second meeting for the revision of "Disaster Measures Guideline for Pet Relief"]. Retrieved June 16, 2019, from https://www.env.go.jp/nature/dobutsu/ aigo/2_data/saigai_guide/h29_02/h29_02b.pdf.

Ministry of the Environment, Government of Japan [Kankyosho]. (2017b). Saigai-ji ni okeru petto no kyugo taisaku gaidorain no kaitei to ni kakaru daiikkai kentokai Giji gaiyo [The proceedings summary of review the first meeting for the revision of 'Disaster Measures Guideline for Pet Relief']. Retrieved June 16, 2019, from https://www.env.go.jp/nature/dobutsu/ aigo/2_data/saigai_guide/h29_01/h29_0lb.pdf.

Ministry of the Environment, Government of Japan [Kankyosho]. (2018). Inu neko no hikitoriri oyobi fusho dobutsu no shuyo jokyo [Taking custody of dogs and cats and containment situation of injured animals]. Retrieved June 16, 2019, from https://www.env.go.jp/nature/dobutsu/aigo/2_data/statistics/ dog-cat.html.

Ministry of Health, Labour and Welfare [Kosei Rodo Sho]. (2018). Heisei 29nen kokumin seikatsu kiso chosa no gaikyo [The general conditions of 2017 life basics survey]. Retrieved January 6, 2019, from https://www.mhlw.go. jp/toukei/saikin/hw/k-tyosa/k-tyosal7/dl/10.pdf.

Ministry of Health, Labour and Welfare [Kosei Rodo Sho]. (n.d.). Inu no toroku tosu to yobo chusha tosu-to no nenji betsu suii (Showa 35-nen Heisei 29nendo) [Annual transition of the number of registration and vaccination of dogs, 1965-2017 fiscal year]. Retrieved August 15, 2019, from https://www. mhlw.go.jp/bunya/kenkou/kekkaku-kansenshoul0/02.html.

National Diet of Japan Fukushima Nuclear Accident Independent Investigation Commission [Kokkai jikocho Tokyodenryoku Fukushima genshiryoku hatsudensho jiko chosa iinkai hokokusho]. (2012). Hokoku-sho (Report) [Pdf file]. Retrieved August 10, 2019, from http://www.mhmjapan.com/con tent/files/00001736/naiic_honpen2_0.pdf. 
National Personnel Authority [Jinjiin]. (2019). Minkan kyuyo no jittai [The actual conditions of private company salary] [Pdf file]. Retrieved August 10, 2019, from https://www.jinji.go.jp/kyuuyo/index_pdf/minn_jittai.pdf.

National Police Agency Emergency Disaster Security Headquarters [Keisatsucho kinkyusaigai keibi honbu]. (2019, June 10). Tohoku chibo Taibeiyo oki jishin no keisatsu sochi to higai jokyo [Police measures and damage situation in the Tohoku Earthquake] [Pdf file]. Retrieved August 10, 2019, from https:// www.npa.go.jp/news/other/earthquake2011/pdf/higaijokyo.pdf.

NHK [Nippon Hoso Kyokai Japan Broadcasting Corporation]. (2018). Do berasu? Inu neko no sasshobun - NHK kurozuappu gendai + (Purasu) [How do you reduce it? Slaughter of dogs and cats-NHK close-up nowadays + (plus)]. 24 January 2018. Retrieved August 10, 2019, from https://serai.jp/ living/167944.

Nozawa, K., \& Takao, N. (1981) Kachiku to Ningen [Domestic animals and human being]. Tokyo: Idemitsu Shoten.

Ota, K. (2012). Machi tsudzukeru dobutsu-tachi Fukushima dai ichi genpatsu 20-kiro ken'nai no sore kara [Animals who keep waiting: And then after that within $20 \mathrm{~km}$ of Fukushima Daiichi nuclear power plant]. Tokyo: Asukashinsha.

Ozaki, Y. (2004). Petto shiiku no kitei yoin: Nipponban sogo shakai chosa maikurodeta o mochiite [Factors that influence owning pet: By using Micro Data of JGSS]. Seikatsu keizai-gaku kenkyu [Journal of Personal Finance and Economics], 19, 21-34.

Ozaki, Y., \& Sakurai, F. (2002). Jui-gyo no doko: Kakushu no tokei shiryo kara [Trends in the veterinary industry: From various statistical data]. Nihonjuishikai zasshi [Journal of the Japan Veterinary Medical Association], 55(8), 533-539.

Real Estate Economic Institute [Fudosan keizai kenkyujo]. (2008, April 3). Puresu ririsu: Shutoken ni okeru petto shiiku kanona bunjo manshon fukyuritsu chosa [Press release: Diffusion rate survey of pet-friendly condominiums in Tokyo metropolitan areas].

Real Estate Distribution Research Institute, Inc. [Kabushikigaisha fudosan ryutsu kenkyujo]. (2008). Shutoken manshon, "petto shiiku-ka" ga 80-pasento toppa [Metropolitan area apartments, "pet-friendly" over 80\%]. https://www.report.net/article/news/0000015467/.

Reconstruction Agency [Fukko-cho]. (2018, December 28). Higashinihon daishinsai ni okeru shinsaikanren shi no shisha-su [Number of deaths from disaster-related deaths in the Great East Japan Earthquake] [Pdf file]. Retrieved August 10, 2019, from http://www.reconstruction.go.jp/topics/ main-cat2/sub-cat2-6/20181228_kanrenshi.pdf.

Ryukyu Shinpo. (2018, August 25). Inu joto 8-wari borantia sasshobun-gen no ura, dantai hihei "kaunara saigomade" [Adaption of dogs, 80\% volunteer: 
Behind the reduction of killings, group exhaustion. "If you keep animals, until their end of life"]. Rynkyu Shinpo. Retrieved August 10, 2019 from https:// ryukyushimpo.jp/news/entry-790251.html.

Sato, S. (2013). Higashinihon daishinsai to Tokyodenryoku Fukushima dai ichi genpatsu jiko ni tomonau Tohoku no chikusan no genjo to mirai [Current status and the future of Livestock farming after the Great Eastern Japan earthquake]. In H. Yoshino \& M. Hino (Ed.), Imawoikiru - Higashinihon daishinsai kara ashita e! Fukko to saisei e no teigen - 5 shizen to kagaku [Living now-From the Great East Japan earthquake to tomorrow! Proposals for reconstruction and regeneration-5. Nature and science] (pp. 23-27). Sendai: Tohokudaigaku shuppan-kai [Tohoku University Press].

Utsunomiya, N. (1999). Petto to Nihonjin [Pet and Japanese]. Tokyo: Bungeisyunjyu.

Yamaji, K. (2013). Saigai fukko koei jutaku to petto shiiku no kadai: Higashinihon daishinsai no fukko ni Hanshin Awaji daishinsai, Chuetsu jishin no keiken o ikasu (Tokushu Higashinihon daishinsai to bosai 2) [Disaster reconstruction public housing and pet keeping issues: Leveraging the experience of the Great Hanshin-Awaji Earthquake and Chuetsu Earthquake in the reconstruction of the Great East Japan Earthquake (Special issue: The Great East Japan Earthquake and Disaster Prevention 2)]. Hyogo chiri [Hyogo Geography], 58, 1-8.

Yano Research Institute Ltd. (2018). Press Release No. 1892 (24 May 2018) Petto bijinesu ni kansuru chosa o jisshi [A survey on pet business was conducted]. Retrieved October 30, 2018, from https://www.yano.co.jp/ press-release/show/press_id/1892. 